\title{
Legal Research- Descriptive Analysis on Doctrinal Methodology
}

\author{
Pradeep M. D. \\ Research Scholar, School of Law, Alliance University, Bengaluru, Karnataka \& Assistant \\ Professor, School of Social Sciences and Humanities, Srinivas University, Karnataka, India \\ Email: mdpradeepnair767@gmail.com
}

Area/Section: Socio-legal Research.

Type of the Paper: Research Paper.

Type of Review: Peer Reviewed as per $|\mathrm{C}| \mathrm{O}|\mathrm{P}| \mathrm{E} \mid$ guidance.

Indexed in: OpenAIRE.

DOI: http://doi.org/10.5281/zenodo.3564954.

Google Scholar Citation: IJMTS.

How to Cite this Paper:

Pradeep, M. D. (2019). Legal Research- Descriptive Analysis on Doctrinal Methodology. International Journal of Management, Technology, and Social Sciences (IJMTS), 4(2), 95-103. DOI: http://doi.org/10.5281/zenodo.3564954.

International Journal of Management, Technology, and Social Sciences (IJMTS)

A Refereed International Journal of Srinivas University, India.

IFSIJ Journal Impact Factor for $2018=4.764$

(C) With Author.

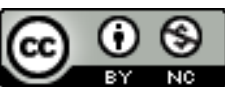

This work is licensed under a Creative Commons Attribution-Non Commercial 4.0 International License subject to proper citation to the publication source of the work.

Disclaimer: The scholarly papers as reviewed and published by the Srinivas Publications (S.P.), India are the views and opinions of their respective authors and are not the views or opinions of the SP. The SP disclaims of any harm or loss caused due to the published content to any party. 


\title{
Legal Research- Descriptive Analysis on Doctrinal Methodology
}

\author{
Pradeep M. D. \\ Research Scholar, School of Law, Alliance University, Bengaluru, Karnataka \& Assistant \\ Professor, School of Social Sciences and Humanities, Srinivas University, Karnataka, India \\ Email: mdpradeepnair767@gmail.com
}

\begin{abstract}
Human beings possess instinct of inquisitiveness in cases of confronting with the unknown aspects of life which probe to attain greater understanding on such uncertainty. This inquisitiveness is the method which man employs for obtaining knowledge is termed as research. It is the art of scientific enquiry into new facts conducted in any branch of knowledge. Generally, Research is the movement from the known towards the unknown to be called as the voyage of discovery. It originally contributes to the existing stock of knowledge facilitating its advancement. Truth is pursued with the help of study, observation, comparison and experiment. Systematic study of the law through doctrinal and non-doctrinal research methods considers to be the socio-legal studies aiming to analyze the impact of legal mechanism on the social system. This paper introduces into the fundamentals of legal research, socio-legal studies, conceptual framework on doctrinal research, steps of doctrinal studies, limitations and differences between doctrinal and non-doctrinal legal research methods.
\end{abstract}

Keywords: Knowledge, Socio-legal Research, Doctrinal and Non Doctrinal, Scientific Enquiry.

\section{INTRODUCTION :}

Research is considered to be the structured inquiry with acceptable scientific methodology to solve problems by creating knowledge which is universally acceptable [1]. Task of knowing anything scientifically with proper inquisition or search for facts is considered to be the research. Law research seem to be the investigation conducted by the researcher to find out the reason or context behind such enactment or any subsidiary related aspects connected to legal mechanism with universally accepted methodology of study. A systematic study into the social, political and economic facts giving ways for the individual rules and its impact upon the society becomes fact research in law. Scientific methodology comprises of systematic observation, classification and interpretation of data. Normally people engage in casual enquires in the course of their daily lives. But main difference between the day to day generalization and scientific method lies upon the existing degree of formality, rigorousness, verifiability and general validity [2]. The objective of the traditional legal research was evaluative, impact analysis or projective. Those studies are evaluative in its character if such study investigates on the origin of any law and its societal implication. For example, a search seeking to inquire into the social roots of freedom of information and its regulation through law for the sake of ensuring good governance seems to be analytical type of work. If the research works with an intension to give clarity on the matter of law starts elaborating on features, significance and sources of law such studies are considered to be explanatory type of research works. For instance, any research conducted to evaluate the legal safeguards put forth by different laws upon industrial intellectual property falls within the preview of explanatory researches. Law research aims to ensure economic system which is operating rather than inhibit or retarding such system. As 
a result of legal research, the decision makers can identify ranges of alternative policy choices connected to economy essential based on the appropriate requirements of the substantive and procedural laws to regulate economic system. If the research work emphasizes on the determination of merits of enactment of any law then such work gains the status of exploratory researches. For ex, the research conducted to find out the utility of Land Reform Laws.

\section{SOCIO-LEGAL RESEARCH :}

Holmes depicts law as logical facts and experiences which creates an approach [3]. Legal research is the systematic investigation of problems connected to. Since law originates and functions within the society studying it in the isolation has no meaning. The non-functionality of law in the social context in the nineteenth and first half of the twentieth century lead for the emergence of newer approach to study law by socio-legal research. The aspects related to the need for a new law or demand for any change in the existing law and difficulties posed during the implementation can be understood only by conducting socio-legal inquiry. Integration of social and legal research is essential for creating better administration of the society. No discipline remains ideal with the growing complexity of modern society. Discipline of law is also not an exception in this regard. Each legal rule is concerned with its application to a factual situation of life hence gives a way for all the intellectual disciplines to connect with law. This distinct relationship of law with other disciplines compels the researchers to expand their investigation and enquiry beyond law onto the roots of other disciplines also. The impact any socio-legal research highly depends on the depth of knowledge possessed by the researchers both in law and allied fields. Socio-legal research seek to facilitate law reforms in the areas of social welfare [4]

\section{DOCTRINAL RESEARCH :}

Basically, research is the investigation of the new thing or first-hand experience. The sociolegal research is basically conducted in different forms by way of doctrinal and non-doctrinal research methods. The word 'Doctrine' was derived from the Latin word 'Doctrina' means to instruct or precept. Doctrine is known to be the synthesis of rules, principles, norms and values which justify any segment of law and presumes to be a part of general law [5]. According to S.N. Jain, former Director of Indian Law Institute, New Delhi, The Doctrinal Research performs legal way of thinking or derive conclusions upon rational observations by analysing the propositions pronounced by the legal institutions on the basis of case laws it has decided [6]. Doctrinal studies deal with searching unknown facts with the help of review of legal materials to conclude on the matters connected to legal system, policies, laws and judgments of the judiciary without depending on primary study from the field. Ancient Legal research attempts to solve problems on the basis of enacted laws since it possesses primary authority imposed through the sanction authorized by the legal entity.

(a) Scope of Doctrinal Research: Doctrinal Research is established as the traditional source of Research in law since Law professionals were intensively dependent on it to derive logical conclusions on legal matters. Legal research helps to contribute outstanding research works with quality. Doctrinal studies propose identical solutions to most of the problems connected to law with minimum expenditure and time after analysing the synthesis of well-established doctrines, polices and court decisions through scientific, reasonable and efficient methodology. Doctrinal study don not ordinarily test the hypothesis as like it is done in the Non doctrinal studies [7]. Doctrinal research allows the lawyers and scholars to undertake comparative study with broader abstraction over the legal problem [8]. Legal doctrine presents the law as a coherent net of principles, rules and exceptions long the levels of abstraction even though the system is coherent always [9]. The objectives of Doctrinal Research are specified below.

- Establish new legal theory, principal, doctrines to add resources to the domain of legal discipline.

- Appropriate application of legal doctrines through analyzing the 
authoritativeness of such laws, cases, principles, doctrines etc.

- Guiding the legal professionals in deriving right decisions by facilitating required authoritative evidences.

- Developing Theories to explain the context of implications of substantive and procedural laws on the society to improve the interpretation of law.

(b) Researcher: Every professional expert such as doctors, pharmacist, physiotherapist, lawyers, engineer etc is also considered to be the researchers. In the same manner, people connected to legal profession such as judges, advocates, academicians, scholars, journalists and students are the researchers who want to know the social impact of any substantive or procedural law.

(c) Research Objectives: Objectives are the goals the researcher set to attain through the study. Objectives framed for the study shall explore the significant aspects to be dealt for scientific enquiry and establishing correlation and associations between the concepts of law. The Research design used by the researcher shall be in accordance with the objectives identified to be dealt under the legal exploration. The objectives framed for the study shall be very precise without creating any uncertainty connected wholly to the genesis of study. The researcher shall elaborate the relevance of objectives connecting it to the title of the study be emphasizing the relevance. The researcher shall highlight upon the functioning of legislative regime and its challenges which made him to choose the particular problem for this research.

(d) Research Laboratory: Research in the science discipline are usually carried within the well-established laboratories, but doctrinal studies in law are possible to be conducted in the places such as libraries with sufficient law materials to refer and use. Researcher can use the online sources, books, journals, magazines, law reports, bulletins, newspapers, library catalogues, public documents, thesis, reference books, judicial reports, articles, websites etc.

(e) Sources for the Research: The sources used to conduct the doctrinal research are authoritative. The original sources of legal information acts as the 'Primary Sources comprising the original materials on Legislations and Precedents. Legislations are the acts enacted by both Houses of the people and State Legislatures respectively. The Cases decided by the Supreme Court and High Courts of the States are vested with the power of Precedents with binding force upon the lower Courts in the Interpretation of Justice on similar facts and circumstances. Besides the original sources, in its absence the researchers can depend on the Secondary Sources. However, Text Books, Commentaries on Constitution of India and Commentaries on Law can also be referred even though its authority falls below than the original sources. Therefore, the credibility of the doctrinal outcomes depends highly on the type of legal materials upon which the conclusions are derived. The aim of the study is to verify hypothesis with further enquiry, the doctrinal legal research attempts to verify the hypothesis by a first-hand study of authoritative sources. The researcher conducting doctrinal works shall equip to make the best use of authoritative legal materials available in the libraries by adopting requisite research methodology.

(f)Formulation of Hypothesis: It is a tentative statement in the form of proposition incepted to review its acceptance or rejection [10]. Hypothesis is a presumed statement made by the researcher with a task of either proving its validity or disproving its relevance. It acts to be the question to be addressed through the results of the research study. Therefore, we can derive that, hypothesis is a proposition identified to prove the happening of any phenomena as a temporary specification or as the most accepted probability based on the facts which are well established. Any hypothesis needs to be featured with the elements of clarity, precision, testability, provides opportunity to study the association existing between the different variables, specific, limited within the scope, simple, relate itself with facts in reality and must explain the facts that gave rise to the need for explanation.

(g) Research Methodology: Methodology in research is considered to be the pedagogy opted 
to derive solutions to the research problem. It is also known to be the science behind conducting any scientific research studies. Methodology depicts about methods and procedures to be used according to the circumstances of the study. It also elaborates about the reason why a particular technique is used to analyze the research results. It describes about the scope of research study, the background of the research problem, basis for the formulation of hypothesis, tool used for collecting the data and techniques used for analyzing the data [11]. Doctrinal Research develops legal proposition in order to testing it based on the authoritative sources including case laws, precedents of Supreme and High Courts, prior studies, reports, academic writings

(h) Research Design: Research design is a plan of the proposed research work. It is also considered to be the blue print of research providing information on future courses of action, processes and techniques adopted to solve the researchable question. It is the complete course of action planned under the research schedule. Research Design provides information on different tasks of the researcher since from identifying the hypotheses to analysis of data in order to derive conclusion [12]. Basically, descriptive and exploratory research designs are usually used in doctrinal researches. The research design provides information on the following aspects.

- The area of the research and the relevance of primary or secondary data.

- Rationality and Significance of the study.

- Appropriate sources identified by the researcher along with reason to support such selection.

- The study population after specifying the limits in clear terms based on both inclusion and exclusion criteria.

- The approximate duration of time essentially required to complete the fullfledged study.

- The quantity of legal material including case laws, laws, policies, commentaries etc.

- The tool used to collect data which is more relevant.
- The methodology used for data analysis and interpretation.

- Financial base of the research specifying the total expenditure, aid or sponsorships etc.

- Exploration on the type of research by highlighting the specific nature of the study.

\section{STEPS IN DOCTRINAL RESEARCH :}

The doctrinal research is carried with several steps which are explained below.

(a) Assembling Facts, Legal Issues for Study: In Doctrinal Research problem for research can be possible by assembling relevant facts on the topic related to law. The researcher should identify the legal issues connected to the chosen area. Reasoning shall be done to scrutinize the connected issues for searching the laws involved in it. Formulating research problem is the first step in the research process. The researcher should know the problem in order to solve such problem. It can be said that a large part of the problem lies in knowing what the researcher is trying to do [13]. The researcher shall follow different rigid phases to formulate a feasible research problem for which it is essentially required to develop required level of knowledge on the area of study.

(b) Literature Review: Searching for relevant literature extensively seems to be in consistent throughout the study where it starts even before choosing the research problem and continues throughout the research extending its reach until the process of reporting of research outcome. The research fraternity has felt the existence of 'paradox' connected to research problem and literature review as 'extensive literature review highly depends on the research problem identified for the scientific enquiry whereas formulating such research problem highly depends on the extensive quality literature'. Literature review gives more precision to the research methodology by building knowledge base for the research problem identified. Reviewing the literature connects the body of knowledge under which study is opted with the expected research outcome aspired through the scientific study [14]. It is also considered to be 
the process of searching for available information in the area of study in order to conclude the theoretical base to derive concrete foundation to establish the conceptual clarity. Exploration on the relevant literature is established by referring to the published works on the relevant concepts in the reputed journals and books by the eminent authors. Additional sources of information depicting data on primary authority of law includes Cases, Statutes and Regulations etc. and Secondary Authority including Books, Treaties, Card Catalogue, Nutshells, Handbooks, Encyclopedia, Treatise, Everything about that particular field of law and Law Reviews/Periodicals etc. Secondary source leads the researcher towards the primary sources which will help to interprets general sense of law, background, statutes and cases. The process of review on the above-mentioned sources will enrich the familiarity of the researcher on the area of study. The way of formulation of a problem determines the type of study design, the search instruments could be used, the type of analysis that could be used. The following steps can be followed to finalize the research problem. Firstly, identify the broad field or subject area of interest for the researcher. Secondly, dissert the broad area into subareas. Finally, raise the research questions on what is to be found out? The review shall be carried through the legal textbooks, policy papers, law reports, legislations, journal articles, magazines, law reviews, bulletins etc. There are many government and semi-government organizations collecting data on a regular basis and publishing in the form of reports and forecasts with statistics about Census, Public Affairs, Health, Employment, Economic Forecasts and Demography etc. These sources can be used as primary sources since it is published with authority. Legal researchers are encouraged to refer to the works which are published in the area of study to increase feasibility. It is advised to refer to studies published in the paid online legal research databases having international reach including Westlaw International, HeinOnline, LexisNexis, JSTOR, E-Hart or refer the national level data bases such as Manupatra, Indlaw, SCC Online, AIR SC \& High Courts,
AIR Criminal Law Journal, Corporate Law Advisor etc.

(c) Analysis: The researcher discusses on the problem of study by referring to the concerned Statutes, Case Laws, Court Decisions etc. This part will discuss every dimensions of the problem by highlighting the impact of law on the social system. The analysis will be carried in the following two ways

(i) Comprehensive Analysis on Case Laws: Rules and principles both expressed and relied upon by the juries in the course of pronouncing the judicial decisions. The judgments pronounced by the apex courts including high courts and supreme courts gains the authority of 'Precedent' to be followed by the lower courts within the legal regime of India. The wellestablished 'Doctrine of Precedent' proposes that specific grounds upon which juries have come to the consensus to decide upon the case shall hold the power of precedent rather upon any other interpretations made in such due course. In an appeal cases, the reason provided in the judgment of the lower court shall become the subject matter for research. Case Law Analysis identifies the prime aspects in the judgment considering the history, facts and circumstances of the case in the light of arguments for and against delivered in the court of law, critical examination of the majority and minority views on the case and final conclusion as to the right [15].

(ii) Analysis over the Legal Theory: The intention of a theory is to summarize existing knowledge to provide an explanation on the observed events by exposing the relations embodied in the conceptual framework. John Galtung conceives theory as a set of hypotheses structured by the relation of implication of deductibility. Doctrinal Research helps to initiate recasting and refocusing and clarification of existing theories. The following roles are played by the theories.

- Theory provides significant guidelines for conducting research by pointing the areas which are likely to be fruitful by revealing the areas in which meaningful relationships among variables can be found. 
- Theory provides the researcher with definite viewpoints.

- Theory enhances the meaningfulness of the findings of a given study by making it possible to perceive them as special cases of the operation.

- Theory provides more general or abstract statements of relationships rather depicted the isolated bits of empirical information.

(d) Conclusion and Suggestions: It also quotes proper suggestions for the improvement of the Legal System for the Social Welfare. It opens new avenues for further research. The general comment on the significance of a piece of research and the location of the research work in the general body of knowledge will be attempted here. The study conclusion will give completeness and positive gains to the research work.

(e) Research Reporting: The information collected through library research has to be presented in an organized and structured way. The research report shall contain the following chapters. The research report shall consist of preliminaries, main text and the reference materials. The Preliminary comprises of title page, certificates, acknowledgement, preface and table of contents. The Main text comprises of the chapters on introduction, objectives of the study, methodology, main body of the report, analysis and discussions, findings, suggestions and conclusions. The reference materials consist of bibliography and appendixes. Bibliography is where the researcher quotes all the references of his study. Quality research should follow recognized citation styles. Citation denotes novelty and legitimacy to the information by providing clarity to the sources of data. The legal researchers are required to follow any of the following styles while citing the works referred which are prominently used such as (a) Blue Book (b) MLA and (c) ILI.

All the works shall be cited to the credit of original author. Hence any proposition made in the research by using others work shall be cited with such original author who has proposed such content first time in order to acknowledge his efforts and contribution to the knowledge domain. The Blue Book Mode of Citation follows the following format throughout the research [16].

(i) Book Published:(a) Author, (b) Title (c) Page Number, (d) Edition, Publication \& Year Publication.

(ii)Law Review Article:(a) Author, (b) Title (Italic), (c) Volume, (d) Name (Abbreviated), (e) Page Number (f) Year of Publication.

(iii)Newspaper Article:(a) Author, (b) Title (Italic), (c) Publication (Capital), (d) Date\& Page. (iv) Case Laws: (a) Name of the Parties (Italic), (b) Volume, (c) Page Number, (d) Year.

(v) Internet Document:(a) Author, (b) Title (Italic), (c) Date of Publication (Bracket), (d) URL.

\section{ANALYIS AND DISCUSSION :}

(a) Limitations of Doctrinal Research: The scientific enquiries have not protected legal scholars from the limitations inherent with the legal research methodology [17]. This study depicts even that, doctrinal research is not free from limitations which amplifies efforts to establish new trend by the legal research fraternity. The credibility of the doctrinal research depends on the availability of literature. Any lack by the researcher in his effort to collect most relevant literature both from primary and secondary sources having authenticity turns the research findings to be null. Twenty first century is the era of interdisciplinary researches where studies are about the impact of law over other disciplines. Theoretical outcome derived from the doctrinal research being so conservative will not expose the implications of law over social system. Doctrinal Research generates research gap which could only be filled through conducting non doctrinal studies exploring the relationship between law and society. Doctrinal methodology presumes law in isolation to be operative in vacuum but in reality, law operates within the social system. There is also abundant scope left for the utilization of inter-disciplinary research methodology to derive more empirical results over the aspects of law.

(b) Merits of Doctrinal Research: This research is included and taught within the formal curriculum of the legal training hence legal 
researchers are well exposed to the methodology. This type of research is mostly approved by the law schools, law firms, practitioners and professors etc. The research outcomes are predictable since it relies on the established sources of legal materials.

(c) Distinguishing Doctrinal from Non Doctrinal Researches: From the above discussed matters it is important to distinguish doctrinal research from the non-doctrinal researches. These differences are drawn clearly in the table- 01 .

Table1: Doctrinal V/S Non Doctrinal Research

\begin{tabular}{|l|l|}
\hline \multicolumn{1}{|c|}{$\begin{array}{c}\text { Doctrinal } \\
\text { Research }\end{array}$} & \multicolumn{1}{c|}{$\begin{array}{c}\text { Non Doctrinal } \\
\text { Research }\end{array}$} \\
\hline $\begin{array}{l}\text { Deals with Legal } \\
\text { Doctrines, } \\
\begin{array}{l}\text { Concepts, Rules, } \\
\text { Principles, } \\
\text { Doctrines etc. }\end{array}\end{array}$ & $\begin{array}{l}\text { Deals with Social } \\
\text { Problems connected to } \\
\text { people, society, } \\
\text { institutions etc. }\end{array}$ \\
\hline $\begin{array}{l}\text { Depends on the } \\
\text { Law, Policies, } \\
\text { Conventions, } \\
\begin{array}{l}\text { Treaties \& } \\
\text { Precedents and } \\
\text { Court Decisions }\end{array}\end{array}$ & $\begin{array}{l}\text { Depends on the field } \\
\text { Study adopting the tools } \\
\text { Questionnaire, } \\
\text { Observation etc. }\end{array}$ \\
\hline $\begin{array}{l}\text { Extensive usage of } \\
\text { Secondary Data } \\
\text { having Authority. }\end{array}$ & $\begin{array}{l}\text { Extensive usage of } \\
\text { Primary Data }\end{array}$ \\
\hline $\begin{array}{l}\text { Concerned with } \\
\text { Documents }\end{array}$ & $\begin{array}{l}\text { Concerned with issues } \\
\text { connected to Society \& } \\
\text { People. }\end{array}$ \\
\hline $\begin{array}{l}\text { No Training is } \\
\text { required to collect } \\
\text { Data }\end{array}$ & $\begin{array}{l}\text { Training is required to } \\
\text { collect the first hand } \\
\text { Information. }\end{array}$ \\
\hline $\begin{array}{l}\text { Research laboratory } \\
\text { is library }\end{array}$ & $\begin{array}{l}\text { Research laboratory is } \\
\text { Society }\end{array}$ \\
\hline
\end{tabular}

\section{CONCLUSION :}

Law governs the society which is produced through legislative decision making process subjected to the public acceptance. Law is a system of representing inherent theories, doctrines, principles, rules, guidelines and exceptions at different contextual abstraction [18]. The fundamental research with socioscientific approach shall become an integral part of the law professionals to acquire the required skills and attributes to galore in their profession
[19]. Legal research aims to analyse about the impact of legislations through established legal propositions and testing it logically. The democracy encourages peoples to participate in the decision making process enhancing opportunities for conducting doctrinal studies. Doctrinal Research with projective or predictive methodologies analysing the established doctrines and authoritative sources to measure the social acceptance, legal-social connectivity, impact of law over public welfare essentially contributes in the development of effective administration of justice which is the virtue of human life. Academic legal research should engage in deriving answers for the intension behind enacting the law instead of searching for alternatives to solve the problems of the legal system [20]. The research should develop skills and abilities to establish integrated doctrinal and socio-legal studies along countering existing limitations to derive quality research outcomes is the need of the day [21]. The researcher should decide either to use basic or applied research methodology based on the problem identified by him and solution expected in that regard [22].

\section{REFERENCES :}

[1] Grinnell, Richard (1993). Social Work, Research and Evaluation. Itasca Illinois, F.E. Peacock Publishers, $3^{\text {rd }}$ Edition.

[2] Lundberg, George A. (1942). Social Research-A Study in Methods of Gathering Data. Longmans, Green \& Co, $2^{\text {nd }}$ Edition, New York.

[3] Holmes jr O.W. (1897). The Path of Law.Harvard Law Review, 457- 469.

[4] Vijay M Gawas. (2017). Doctrinal Legal Research Method a guiding Principle in Reforming the Law and Legal System towards the Research Development. International Journal of Law, 3(5), 128130 .

[5] Terry Hutchinson \& Nigel Duncan (2012). Defining and Describing What We Do: Doctrinal Legal Research. Deakin Law Review, 17(1), 84. 
[6] Myneni S. R. (2014). Legal Research Methodology. Allahabad Law Agency, Faridabad, 40.

[7] Anwarul Yaqin (2008). Legal Research and Writing Methods'. Lexis Nexis, Reed Elsevere Indian Pvt. Ltd., Haryana, India, 29.

[8] John C. Reitz. (1998). How to do Comparative Law?. American Journal of Comparative Law, 46, 625-626.

[9] Pecznick, A. (2001). A Theory of Legal Doctrine. Ratio Juris, 14(1), 75-105.

[10] Black, James A. \& Dean J. Champion (1976). Methods and Issues in Social Research. John Wiley \& Sons, Inc., New York.

[11] Kothari C.R. (2004). Research Methodology Methods and Techniques. New Age International (P) Ltd, New Delhi, $2^{\text {nd }}$ Revised Edition, 1 .

[12] Kerlinger, Fred N. (1986). Foundations of Behavioural Research. Holt, Rinehart and Winston, $3^{\text {rd }}$ Edition, New York.

[13] ibid.

[14] Martin, David W., (1985). Doing Psychological Experiments. Brooks/Cole Publishing Company Monterey, California, $2^{\text {nd }}$ Edition.

[15] Frederic Charles Hicks (1923). Materials and Methods in Legal Research. Lawyers Cooperative Publishing, New York.

[16] Harvard Law Review Association (1926). The Bluebook: Uniform system of Citation. Harvard Law Review, Harvard.

[17] Robin Feldman (2009). Law's Misguided Love affair with Science. Minnesota Journal of Law, Science and Technology, 10(1), 95-116 (97, 115).

[18] Pecznick A. (2001). A Theory of Legal Doctrine. Ratio Juris, 14(1), 75-105.

[19] Burns K \& Hutchinson T. (2009). The impact of Empirical Facts on Legal Scholarship and Legal Research Training. The Law Teacher, 43(2), 153-178.

[20] Mc Conville M. \& Hong Chui W. (2007). Research Methods for Law. Edinburgh University Press, Edinburgh, 2.

[21] Ashish Kumar Singhal \& Ikramuddin Malik. (2012). Doctrinal and Socio-legal Methods of Research: Merits and Demerits. Educational Research Journal, 2(7), 252256.

[22] Pradeep M.D. (2018). Philosophical review on the Basic \& Action Research MethodsA Critical Analysis. International Journal of Management, Technology and Social Sciences (IJMTS), 3(2), 120-129. *************** 